\title{
Sistem Informasi Manajemen Kelola Data Inventaris Di Kelurahan Dengan Metode Grounded Research
}

\author{
Robby Andika Kusumajaya ${ }^{1}$, Priyadi² \\ ${ }^{1}$ Manajemen Informatika, Universitas Sains dan Teknologi Komputer \\ ${ }^{2}$ Sistem Komputer, Universitas Sains dan Teknologi Komputer \\ robby@stekom.ac.id,priyadi@stekom.ac.id
}

\begin{abstract}
Abstrak
Aset yang dimiliki suatu lembaga atau organisasi merupakan sumber daya penting yang harus dijaga dengan baik, karena inventaris ini merupakan penunjang dari suatu kegiatan organisasi. Dalam kegiatannya aset tesebut banyak mengalami perubahan karena adanya pertambahan maupun pengurangan, hal ini juga terjadi di Kantor Kelurahan Bandungan. Mengacu Permendagri Nomor 17 Tahun 2007 Pasal 4 Ayat 2 mengenai pedoman teknis pengelolaan barang milik daerah Kelurahan Bandungan berkeinginan meningkatkan kinerja yang lebih efektif dan kecepatan operasional terutama dalam mengolah data barang inventaris. Permasalahan yang dialami sampai saat ini masih menggunakan sistem semi-computerized yang masih dinilai kurang efisien dalam segi waktu, tenaga juga biaya yaitu menggunakan aplikasi Microsoft Excel dalam mengelola asset dan barang inventaris.

Semakin berkembangnya teknologi, peneliti melakukan riset yang bertujuan untuk mengembangkan sebuah sistem informasi manajemen pengelolaan data inventaris dengan menerapkan metode grounded research untuk mengetahui informasi yang baik untuk memberikan arahan dalam mengambil kebijakan manajemen dalam melakukan perancangan sistem pengelolaan barang. Dengan adanya sistem ini yang menggunakan Database dalam penyimpanan data, diprogram dengan username dan password sehingga keamanan terjamin, mudah dalam pemakaian dan dalam pencarian data lebih akurat, sehingga mudah dalam menyajikan laporan kepada Kepala Desa atau lembaga pemerintah dalam mengelola inventaris.
\end{abstract}

Kata Kunci : Sistem Informasi; Komputerisasi; Inventaris; arsip; Grounded Research.

\section{Abstract}

Assets owned by an institution or organization are important resources that must be maintained properly, because this inventory is a support of an organizational activity. In its activities, many assets have undergone changes due to increases and reductions, this also happens in the Bandungan Village Office. Referring to Permendagri Number 17 of 2007 Article 4 Paragraph 2 regarding technical guidelines for the management of goods belonging to the Bandungan Village area wants to improve more effective performance and operational speed, especially in processing inventory goods data. The problem experienced until now is still using semi-computerized systems that are still considered less efficient in terms of time, energy and cost, namely using Microsoft Excel applications in managing assets and inventory items.

The development of technology, researchers conduct research that aims to develop an inventory data management information system by applying grounded research methods to know good information to provide direction in taking management policies in designing goods management systems. With this system that uses databases in data storage, programmed with usernames and passwords so that security is guaranteed, easy to use and in the search for data 
more accurately, making it easy to present reports to village heads or government agencies in managing inventory.

Key Words : Information Systems, Computerized, Inventory, Archives, Grounded Research

\section{Introduction}

Perkembangan Teknologi informasi yang semakin cepat menuntut banyak perubahan terutama dalam hal memberikan manfaat untuk meningkatkan efisiensi dan efektifitas dari proses bisnis perusahaan, baik sektor perdagangan, perbankan, dan pendidikan. Kebutuhan efisiensi waktu dan biaya membuat para pelaku bisnis perlu menerapkan teknologi informasi dalam lingkungan kerja[1]. Salah satunya dengan menerapkan Sistem komputerisasi yang dapat mendukung kinerja suatu instansi pemerintahan, dengan ada sistem ini dapat menangani pengolahan data dengan menggunakan teknologi informasi[2]. Sehingga dapat meningkatkan kinerja yang lebih efektif dan kecepatan operasional dan dapat mengurangi terjadinya kesalahan.

Kelurahan selama ini selalu dikaitan dengan pusat pemerintahan kecamatan atau perkotaan, karena pada jaman dahulu sangat jarang wilayah yang jauh dari ibukota kecamatan memperoleh status kelurahan pada dasarnya berstatus desa. Sementara itu tidak sedikit wilayah desa yang berpotensi dan memiliki kapasitas jumlah penduduk yang jauh berada diatas kelurahan. Peralihan desa menjadi kelurahan merupakan upaya kebijakan pemerintah dalam membentuk suatu kelurahan dalam pelaksanaan pelayanan kepada masyarakat. Hal itu terdapat dalam Peraturan Menteri Dalam Negeri Nomor 28 Tahun 2006 Tentang Pembentukan, Penghapusan, Penggabungan Desa dan Perubahan Status Desa Menjadi Kelurahan[3]. Peralihan Desa Bandungan menjadi Kelurahan Bandungan terjadi sejak tahun 1998 dan pemekaran Kecamatan Bandungan sejak tahun 2001. Jarak dari kelurahan sampai pusat kecamatan berjarak 300m, jarak ke kabupaten $24 \mathrm{~km}$ dan jarak ke Ibukota Provinsi $45 \mathrm{~km}$. Kelurahan Bandungan memilik luas wilayah 434,335 km2 dengan jumlah penduduk sebanyak 7.514 jiwa dan 2.452 Kartu Keluarga (KK).

Pada Permendagri Nomor 17 Tahun 2007 Pasal 4 Ayat 2 tentang pedoman teknis dalam pengelolaan barang milik daerah [4], menyatakan bahwa pengelolaan aset atau barang daerah meliputi perencanaan kebutuhan dan penganggaran, pengadaan, penerimaan, penyimpanan dan penyaluran, penggunaan, penatausahaan, pemanfaatan, pengamanan dan pemeliharaan, penilaian, penghapusan, pemindah tanganan, pembinaan, pengawasan dan pengendalian, pembiyaan, dan tuntutan ganti rugi. 
Dikutip dari peraturan pemerintah Republik Indonesia no.24 tahun 2005[5] tentang Aset merupakan sumber daya ekonomi yang dikuasai dan/atau dimiliki oleh pemerintah sebagai akibat dari peristiwa masa lalu dan dari mana manfaat ekonomi dan/atau sosial di masa depan diharapkan dapat di peroleh, baik oleh pemerintah maupun masyarakat, serta dapat di ukur dalam satuan uang, termasuk sumber daya nonkeuangan yang di perlukan untuk penyediaan jasa bagi masyarakat umum dan sumber-sumber daya yang di pelihara karena alasan sejarah dan budaya. Hal ini menjadi acuan Kantor Kelurahan Bandungan merupakan instansi pemerintahan yang bergerak dalam bidang pelayanan masyarakat.

Kegiatan pelaksanaan sehari-hari dalam mengelola data inventaris masih terdapat beberapa kendala dan kesulitan. Belum adanya sistem yang dapat memonitoring barang inventaris karena dengan seiring berjalannya waktu keberadaan asset tetap dan barang yang ada di kelurahan akan mengalami perubahan, baik adanya pertambahan maupun pengurangan, sehingga membuat petugas kesulitan dalam memonitoring asset dan barang yang ada[6]. Informasi yang kurang akurat dan terbaru mengenai barang inventaris yang ada membuat proses pendataan barang berjalan lambat[7]. Selanjutnya mengenai penyimpanan dokumen laporan yang tidak terintegrasi

akan

menyebabkan

kemungkinan data hilang atau terselip.

Dari permasalahan tersebut, maka peneliti bermaksud untuk membuat Sistem Informasi Manajemen Kelola Data Inventaris pada Kelurahan Bandungan dengan menerapkan metode grounded research yang bertujuan untuk mengetahui proses sistem pengelolaan barang yang dilakukan. Dengan adanya sistem ini dapat memberikan kemudahan[8] Aparat Desa dalam mengelola inventaris. Sistem ini menggunakan Database dalam penyimpanan data, sehingga mudah dalam pencarian dan lebih akurat dalam menyajikan laporan[9]. Program yang dirancang berbasis multi user, dan lengkap dengan pembagian hak akses dengan login menggunakan username dan password karena lebih dari satu.

\section{Material and Methods}

Kata "aset" dikenal pertama kali pada pertengahan abad ke-16; berasal dari bahasa prancis “asez/asetz" yang berarti cukup[10].

Penelitian untuk pengumpulan data yang dilakukan menggunakan metode grounded research dengan tujuan mengetahui proses sistem yang berjalan. Grounded Research merupakan sebuah metodologi penelitian kualitatif yang menekankan inovasi teori berdasarkan data observasi empirik pada lapangan menggunakan metode induktif 
(menemukan teori berdasarkan sejumlah data), generatif yaitu temuan lewat beberapa analisis hasil penelitian yang dilakukan di subjek penelitian[11]. Maksud dari penerapan metode ini adalah untuk memperbaiki teori yang digunakan dan dikembangkan dalam mengolah data saat penelitian proses berlangsung. Berikutnya, merumuskan logika dan karakteristik grounded theory sedangkan tujuan yang terakhir adalah untuk mengesahkan penelitian kualitatif. Dengan metode ini, peneliti melakukan pengumpulan data dan analis data dalam waktu yang bersamaan. Sehingga perancangan aset barang yang dibuat berdasarkan fakta yang ada di lapangan. Data yang dikumpulkan dengan kebutuhan sistem yang akan dirancang.

\subsection{Langkah-langkah Pengembangan Sistem}

Dalam melakukan pengembangan sistem informasi manajemen kelola data inventaris yang berbasis multiuser, peneliti menggunakan model pengembangan sistem sebagai dasar pengembangan produk. Model pengembangan sistem dalam penelitian yang digunakan ini adalah Research and Development (R\&D) dari Borg and Gall dengan 10 tahapan[12]. R\&D merupakan metode penelitian yang digunakan untuk menghasilkan produk tertentu, dan menguji keefektifan produk tersebut. Dalam penelitian ini disederhanakan hanya menggunakan 6 langkah proses penelitian dan pengembangan yang dilakukan untuk menghasilkan produk, menguji keefektifan suatu produk[13]. Dapat diuraikan sebagai berikut : (1) Potensi dan masalah, (2) Pengumpulan data, (3) Desain produk, (4) Validasi desain, (5) Revisi desain, (6) Ujicoba produk.

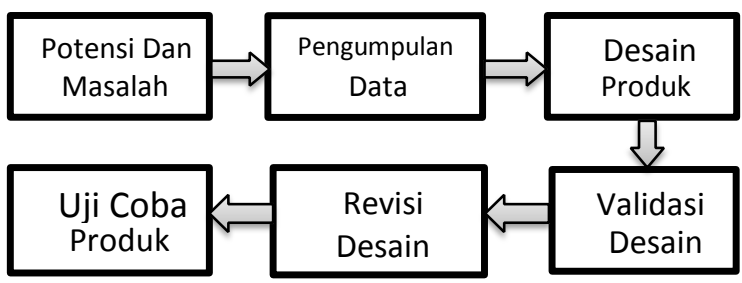

Sumber : Sugiyono, 2017

\section{Gambar 1. Menampilkan Gambar}

Langkah metode pengembangan sistem yang akan dilakukan adalah dengan menemukan potensi masalah dan kebutuhan yang diperlukan dalam suatu lingkup program tertentu pada objek yang diteliti, selanjutnya mencoba menciptakan atau mengembangkan produk baru berdasarkan sistem kerja lama. Penelitian dan pengembangan sistem yang sudah jadi selanjutnya dilakukan dengan pengujian validasi agar dapat diperoleh pengakuan suatu produk yang siap dipakai atau secara umum dapat digunakan. Pada tahap validasi produk melibatkan pakar yang profesional dibidangnya, baik dari dalam maupun dari luar kampus. 


\section{Result and Discussion}

\subsection{ERD (Entity Relationship Diagram)}

Perancangan Entity Relationship Diagram yaitu gambaran relasi dari setiap entity atribut dari file yang dipergunakan untuk menghubungkan data sehingga dapat merancang bentuk laporan atau input data yang diperlukan[14] yang dibutuhkan pada sistem informasi manajemen kelola data inventaris Kelurahan Bandungan sebagai berikut:

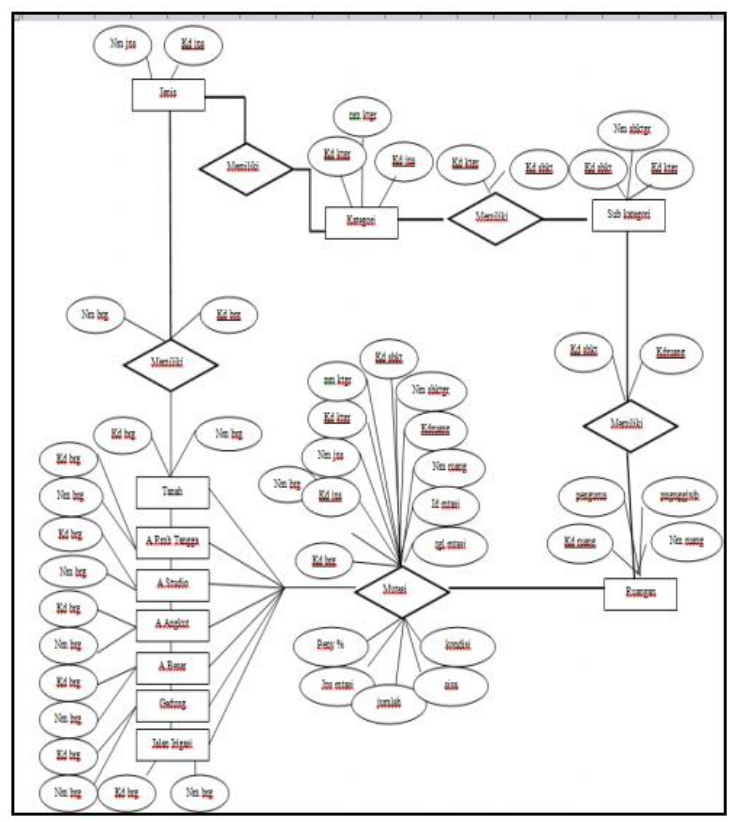

Sumber : Dikembangkan untuk penelitian ini

Gambar 2. ERD Sistem Informasi

ERD di atas ada tiga tabel master yaitu tabel jenis inventaris, kategori inventaris dan subkategori inventaris dan 8 tabel kartu inventaris barang yaitu kelola tanah, kelola alat kantor dan rumah tangga, kelola alat studio dan komunikasi, kelola alat angkutan, kelola alat besar, kelola gedung dan bangunan, kelola jalan dan irigasi serta kelola mutasi. Tabel jenis inventaris di relasikan ke tabel instansi kemudian tabel subkategori inventaris di relasikan pada kelola inventaris barang dan tabel mutasi di relasikan pada kelola alat angkut, kelola alat besar, kelola alat studio untuk penghapusan barang atau pindah ruangan.

\section{Perancangan Database}

Database merupakan salah satu komponen terpenting atau juga utama dalam pembuatan sistem informasi yang dibuat. Penyimpanan data kedalam database membuat data-data laporan yang telah di masukkan menjadi lebih update dan lebih terstruktur[15]. Beberapa tabel yang akan digunakan adalah sebagai berikut:

\section{Tabel 1. Database Tanah}

\begin{tabular}{|l|l|c|c|c|}
\hline No & \multicolumn{1}{|c|}{ Nama Field } & Type & Lebar & Keterangan \\
\hline 1. & *kode_barang & Text & 14 & * primary key \\
\hline 2. & **kode subkategori & Text & 11 & **foreign key \\
\hline 3. & Nama_barang & Text & 100 & \\
\hline 4. & Luas & Number & Long integer & \\
\hline 5. & Hak & Text & 50 & \\
\hline 6. & Sertifikat1 & Text & 50 & \\
\hline 7. & Sertifikat2 & Text & 50 & \\
\hline 8. & Tahun perolehan & Text & 4 & \\
\hline 9. & Penggunaan & Text & 100 & \\
\hline 10. & Asalusul & Text & 50 & \\
\hline 11. & Harga & Number & Long integer & \\
\hline 12. & Letaktanah & Text & 100 & \\
\hline 13. & namapemegang & Text & 100 & \\
\hline
\end{tabular}

Sumber: Dikembangkan untuk penelitian ini

Tabel 2. Database Alat Angkutan 


\begin{tabular}{|c|c|c|c|c|}
\hline No & Nama Field & Type & Lebar & Keterangan \\
\hline 1. & *kode_barang & Text & 14 & *primary key \\
\hline 2. & **kode_subkategori & Text & 11 & **foreign key \\
\hline 3. & Nama barang & Text & 100 & \\
\hline 4. & Merek & Text & 50 & \\
\hline 5. & Tipe & Text & 50 & \\
\hline 6. & Warna & Text & 50 & \\
\hline 7. & Nomor_rangka & Text & 20 & \\
\hline 8. & Nomor_mesin & Text & 20 & \\
\hline 9. & Tahun & Text & 4 & \\
\hline 10. & Nomorpolisi_lama & Text & 20 & \\
\hline 11. & Nomorpolisi_baru & Text & 20 & \\
\hline 12. & Bpkb_nomor & Text & 20 & \\
\hline 13. & Jumlah & Number & Long integer & \\
\hline 14. & Hargaperolehan & Number & Long integer & \\
\hline 15. & Penyusutan_pertahun & Number & Long integer & \\
\hline 16. & Kondisi & Text & 20 & \\
\hline 17. & Asal & Text & 100 & \\
\hline 18. & Keterangan & Text & 200 & \\
\hline 19. & Kode_ruangan & Text & 4 & **foreign key \\
\hline 20. & Status barang & Text & 10 & \\
\hline 21. & Sisamanfaat_neracaawal & Number & Long integer & \\
\hline
\end{tabular}

Sumber: Dikembangkan untuk penelitian ini

\section{Tabel 3. Database Alat Besar}

\begin{tabular}{|l|l|c|c|c|}
\hline No & \multicolumn{1}{|c|}{ Nama Field } & Type & Lebar & Keterangan \\
\hline 1. & *kode_barang & Text & 14 & *primary key \\
\hline 2. & **kode_subkategori & Text & 11 & **foreign key \\
\hline 3. & Nama_barang & Text & 100 & \\
\hline 4. & Merek & Text & 50 & \\
\hline 5. & Tipe & Text & 50 & \\
\hline 6. & Warna & $T e x t$ & 50 & \\
\hline 7. & Nomor_rangka & Text & 20 & \\
\hline 8. & Nomor_mesin & Text & 20 & \\
\hline 9. & Tahun & Text & 4 & \\
\hline 10. & Nomorpolisi_lama & Text & 20 & \\
\hline 11. & Nomorpolisibaru & Text & 20 & \\
\hline 12. & Bpkb_tanggal & Text & 20 & \\
\hline 13. & Bpkb_nomor & Text & 20 & \\
\hline 14. & Jumlah & Number & Long integer & \\
\hline 15. & Hargaperolehan & Number & Long integer & \\
\hline 16. & Penyusutan_pertahun & Number & Long integer & \\
\hline 17. & Kondisi & Text & 20 & \\
\hline 18. & Asal & Text & 100 & \\
\hline 19. & Keterangan & Text & 200 & \\
\hline 20. & Kode_ruangan & Text & 4 & **foreign key \\
\hline 21. & Status_barang & Text & 10 & \\
\hline 22. & Sisamanfaat_neracaawal & Number & Long integer & \\
\hline
\end{tabular}

Sumber: Dikembangkan untuk penelitian ini

Tabel 4. Database Alat Kantor dan Rumah Tangga

\begin{tabular}{|l|l|c|c|c|}
\hline No & \multicolumn{1}{|c|}{ Nama Field } & Type & Lebar & Keterangan \\
\hline 1. & *kode_barang & Text & 14 & * primary key \\
\hline 2. & **kode_subkategori & Text & 11 & **foreign key \\
\hline 3. & Nama_barang & Text & 100 & \\
\hline 4. & Merek & Text & 50 & \\
\hline 5. & Tipe & Text & 50 & \\
\hline 6. & Bahan & Text & 50 & \\
\hline 7. & Tahun_perolehan & Text & 4 & \\
\hline 8. & Jumlah & Number & Long integer & \\
\hline 9. & Nilai_perolehan & Number & Long integer & \\
\hline 10. & Penyusutan_pertahun & Number & Long integer & \\
\hline 11. & Kondisi & Text & 20 & \\
\hline 12. & Asal & Text & 100 & \\
\hline 13. & Keterangan & Text & 200 & \\
\hline 14. & Kode_ruangan & Text & 4 & **foreign key \\
\hline 15. & Status_barang & Text & 10 & \\
\hline 16. & Sisamanfaat_neracaawal & Number & Long integer & \\
\hline
\end{tabular}

Sumber: Dikembangkan untuk penelitian ini
Tabel 5. Database Alat Studio dan Komunikasi

\begin{tabular}{|l|l|c|c|c|}
\hline No & \multicolumn{1}{|c|}{ Nama Field } & Type & Lebar & Keterangan \\
\hline 1. & *kode_barang & Text & 14 & ${ }^{*}$ primary key \\
\hline 2. & **kode_subkategori & Text & 11 & ${ }^{* *}$ foreign key \\
\hline 3. & Nama_barang & Text & 100 & \\
\hline 4. & Merek & Text & 50 & \\
\hline 5. & Tipe & Text & 50 & \\
\hline 6. & Bahan & Text & 50 & \\
\hline 7. & Tahun_perolehan & Text & 4 & \\
\hline 8. & Jumlah & Number & Long integer & \\
\hline 9. & Nilai_perolehan & Number & Long integer & \\
\hline 10. & Penyusutan_pertahun & Number & Long integer & \\
\hline 11. & Kondisi & Text & 20 & \\
\hline 12. & Asal & Text & 100 & \\
\hline 13. & Keterangan & Text & 200 & \\
\hline 14. & Kode_ruangan & Text & 4 & ${ }^{* *}$ foreign key \\
\hline 15. & Status_barang & Text & 10 & \\
\hline 16. & Sisamanfaat_neracaawal & Number & Long integer & \\
\hline
\end{tabular}

Sumber: Dikembangkan untuk penelitian ini

\section{Tabel 6. Database Gedung dan Bangunan}

\begin{tabular}{|l|l|c|c|c|}
\hline No & \multicolumn{1}{|c|}{ Nama Field } & Type & Lebar & Keterangan \\
\hline 1. & *kode_barang & Text & 14 & *primary key \\
\hline 2. & **kode_subkategori & Text & 11 & ${ }^{* *}$ foreign key \\
\hline 3. & Nama_barang & Text & 100 & \\
\hline 4. & Luas_lantai & $T e x t$ & 20 & \\
\hline 5. & Letak & Text & 100 & \\
\hline 6. & Asalusul & Text & 100 & \\
\hline 7. & Tahun_perolehan & Text & 4 & \\
\hline 8. & Jumlah & Number & Long integer & \\
\hline 9. & Nilai_perolehan & Number & Long integer & \\
\hline 10. & Penyusutan_pertahun & Number & Long integer & \\
\hline 11. & Sisamanfaat_neracaawal & Number & Long integer & \\
\hline
\end{tabular}

Sumber: Dikembangkan untuk penelitian ini

\section{Tabel 7. Database Jalan dan Jaringan}

\begin{tabular}{|l|l|c|c|c|}
\hline No & \multicolumn{1}{|c|}{ Nama Field } & Type & Lebar & Keterangan \\
\hline 1. & *kode_barang & Text & 14 & * primary key \\
\hline 2. & **kode_subkategori & Text & 11 & ***oreign key \\
\hline 3. & Nama_barang & Text & 100 & \\
\hline 4. & Luas_lantai & Text & 20 & \\
\hline 5. & Letak & Text & 100 & \\
\hline 6. & Asalusul & Text & 100 & \\
\hline 7. & Tahun_perolehan & Text & 4 & \\
\hline 8. & Jumlah & Number & Long integer & \\
\hline 9. & Nilai_perolehan & Number & Long integer & \\
\hline 10. & Penyusutan_pertahun & Number & Long integer & \\
\hline 11. & Sisamanfaat_neracaawal & Number & Long integer & \\
\hline
\end{tabular}

Sumber: Dikembangkan untuk penelitian ini

\section{Tabel 8. Database Instansi}

\begin{tabular}{|l|l|c|c|c|}
\hline No & \multicolumn{1}{|c|}{ Nama Field } & Type & Lebar & Keterangan \\
\hline 1. & *id_instansi & Autonumber & Long integer & "primary key \\
\hline 2. & provinsi & Text & 50 & \\
\hline 3. & kabupaten & Text & 50 & \\
\hline 4. & Kecamatan & Text & 50 & \\
\hline 5. & Kelurahan & Text & 50 & \\
\hline 6. & **kode_lokasi & Text & 50 & **foreign key \\
\hline 7. & Nama_lurah & Text & 100 & \\
\hline 8. & Nip_lurah & Text & 50 & \\
\hline 9. & Nama_pengurusbarang & Text & 100 & \\
\hline 10. & Nip_pengurus_barang & Text & 50 & \\
\hline
\end{tabular}

Sumber: Dikembangkan untuk penelitian ini 


\section{Tabel 9. Database Ruangan}

\begin{tabular}{|l|l|c|c|c|}
\hline No & \multicolumn{1}{|c|}{ Nama Field } & Type & Lebar & Keterangan \\
\hline 1. & "kode_ruangan & Text & 4 & "primarykey \\
\hline 2. & Nama_ruangan & Text & 50 & \\
\hline 3. & Penanggungjawab & Text & 100 & \\
\hline 4. & pengurus & Text & 100 & \\
\hline
\end{tabular}

Sumber: Dikembangkan untuk penelitian ini

Tabel 10. Database Pengurus

\begin{tabular}{|l|l|c|c|c|}
\hline No & \multicolumn{1}{|c|}{ Nama Field } & Type & Lebar & Keterangan \\
\hline 1. & *nip & Text & 50 & "primarykey \\
\hline 2. & Nama_lengkap & Text & 100 & \\
\hline 3. & Jabatan & Text & 100 & \\
\hline 4. & Jenis_kelamin & Text & 20 & \\
\hline 5. & Username & Text & 30 & \\
\hline 6. & katakunci & Text & 30 & \\
\hline
\end{tabular}

Sumber: Dikembangkan untuk penelitian ini

Tabel 11. Database Jenis KIB

\begin{tabular}{|l|l|l|c|c|}
\hline No & \multicolumn{1}{|c|}{ Nama Field } & Type & Lebar & Keterangan \\
\hline 1. & "kode_jenis & Text & 5 & "primarykey \\
\hline 2. & Nama_jenis & Text & 100 & \\
\hline
\end{tabular}

Sumber: Dikembangkan untuk penelitian ini

Tabel 12. Database Kategori

\begin{tabular}{|l|l|l|c|c|}
\hline No & \multicolumn{1}{|c|}{ Nama Field } & Type & Lebar & Keterangan \\
\hline 1. & Kode_jenis & Text & 5 & ${ }^{*}$ *foreign key \\
\hline 2. & *kode_kategori & Text & 8 & ${ }^{*}$ primarykey \\
\hline 3. & Nama_kategori & Text & 100 & \\
\hline
\end{tabular}

Sumber: Dikembangkan untuk penelitian ini

Tabel 13. Database Subkategori

\begin{tabular}{|l|l|l|c|c|}
\hline \multicolumn{1}{|c|}{ No } & \multicolumn{1}{|c|}{ Nama Field } & Type & Lebar & Keterangan \\
\hline 1. & Kode_kategori & Text & 8 & **foreign key $^{*}$ \\
\hline 2. & *kode_subkategori & Text & 11 & "primarykey \\
\hline 3. & Nama_kategori & Text & 100 & \\
\hline
\end{tabular}

Sumber: Dikembangkan untuk penelitian ini

Tabel 14. Database Mutasi Barang

\begin{tabular}{|l|l|c|c|c|}
\hline No & \multicolumn{1}{|c|}{ Nama Field } & Type & Lebar & Keterangan \\
\hline 1. & *id mutasi & Autonumber & Long integer & "primarykey \\
\hline 2. & Tgl_mutasi & Date/time & & \\
\hline 3. & Jenis_mutasi & Text & 30 & \\
\hline 4. & Kode_barang & Text & 14 & **foreign key \\
\hline 5. & Nama_barang & Text & 100 & \\
\hline 6. & Dari_ruang & Text & 10 & \\
\hline 7. & Ke_ruang & Text & 10 & \\
\hline
\end{tabular}

Sumber: Dikembangkan untuk penelitian ini

\subsection{Application View Results}

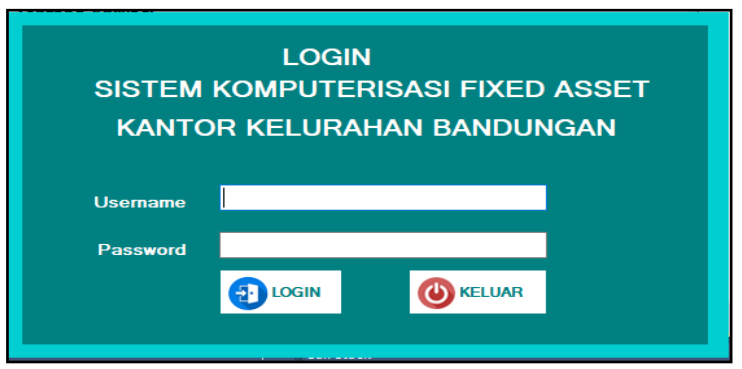

Sumber: Dikembangkan untuk penelitian ini

\section{Gambar 3. Tampilan Form Login}

Tampilan login ini merupakan yang pertama kali muncul pada saat mulai menjalankan aplikasi. Login ini berfungsi untuk memberikan keamanan didalam sistem. Pengurus terlebih dahulu harus mengisi username dan password yang benar sebelum masuk kedalam menu utama.

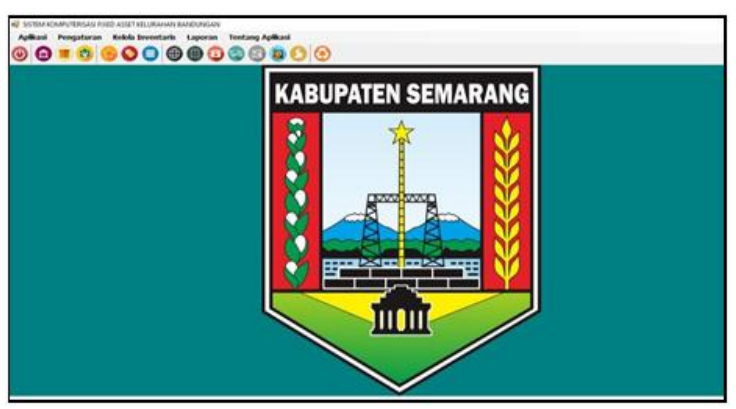

Sumber: Dikembangkan untuk penelitian ini

Gambar 4. Tampilan Menu Utama

Menu utama memiliki beberapa menu yang dapat dioperasikan oleh pengurus.

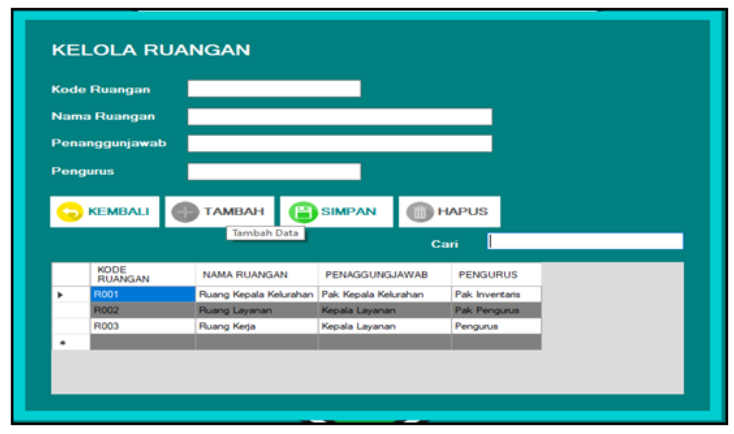

Sumber: Dikembangkan untuk penelitian ini

\section{Gambar 5. Tampilan Form Ruangan}

Form ruangan adalah halaman form untuk mengisi nama ruangan di Kantor Kelurahan Bandungan. Form ini mengisikan kode ruangan, nama ruangan, penanggungjawab dan pengurus. 


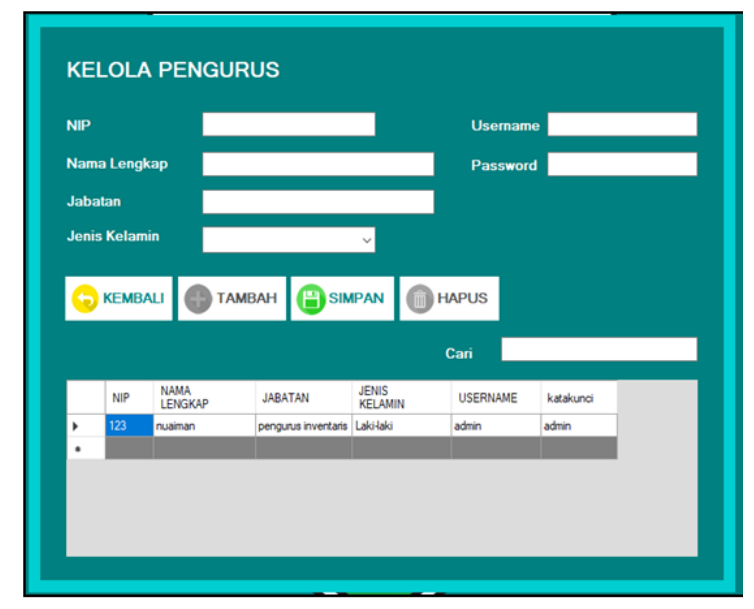

Sumber: Dikembangkan untuk penelitian ini

\section{Gambar 6. Tampilan Form Pengurus}

Form kelola pengurus adalah halam form untuk mengisi data-data pengurus barang yang ada di Kantor Kelurahan Bandungan. Form ini mengisikan NIP, nama pengurus, jabatan, jenis kelamin, username dan password.

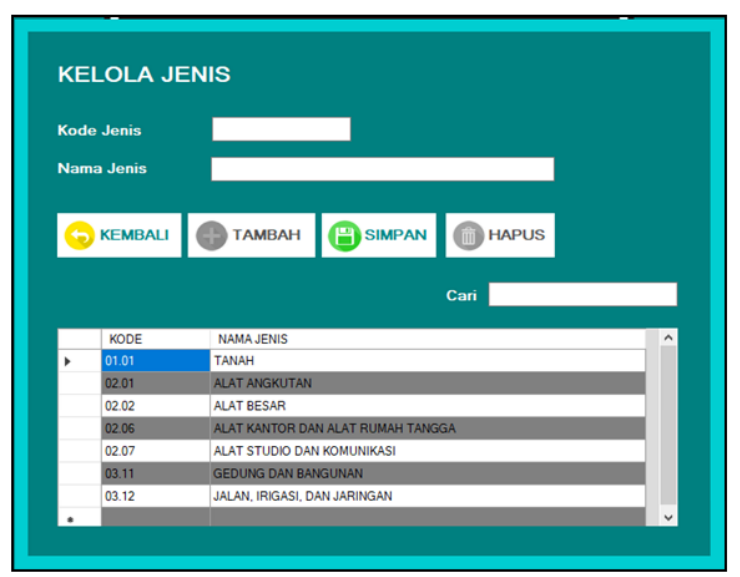

Sumber: Dikembangkan untuk penelitian ini Gambar 7. Tampilan Form Jenis

Form kelola jenis adalah halam form untuk mengisi data-data jenis fixed asset yang ada di Kantor Kelurahan Bandungan.

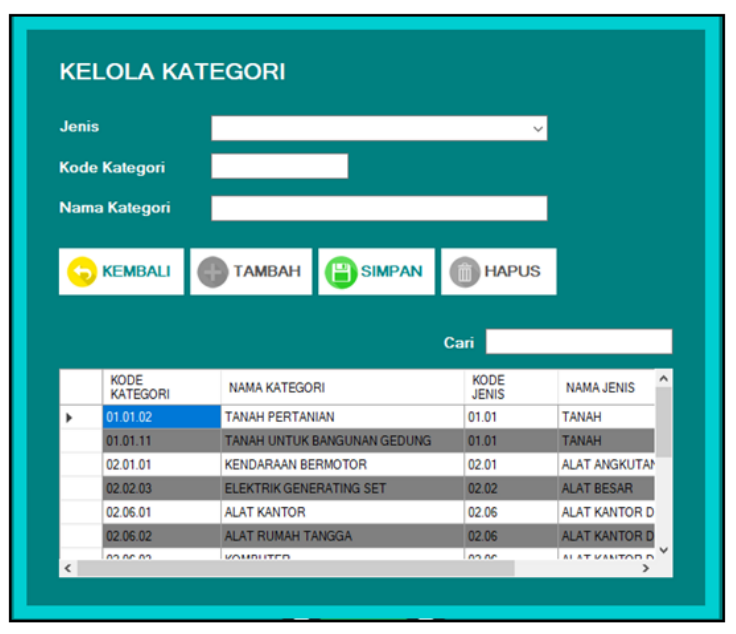

Sumber: Dikembangkan untuk penelitian ini

Gambar 8. Tampilan Form Kategori

Form kelola kategori adalah halam form untuk mengisi data-data jenis kategori fixed asset yang ada di Kantor Kelurahan Bandungan.

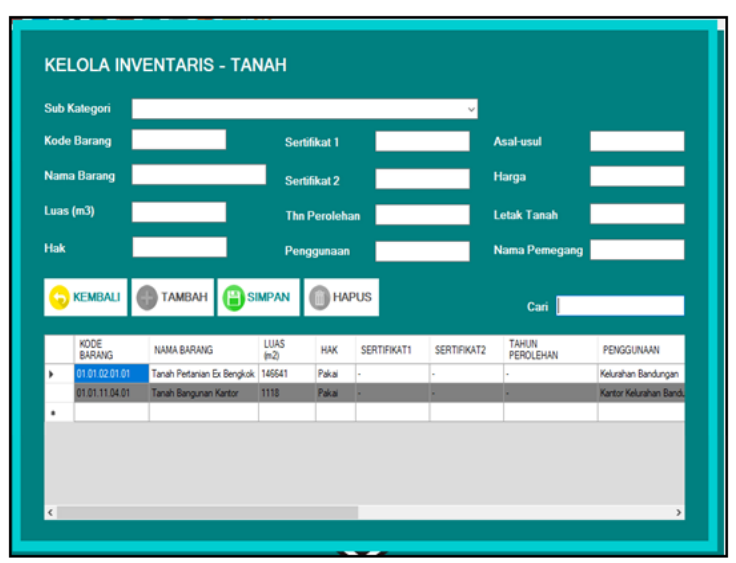

Sumber: Dikembangkan untuk penelitian ini

Gambar 9. Tampilan Form Tanah

Form kelola inventaris tanah adalah halaman form untuk mengisi data-data inventaris tanah yang ada di Kantor Kelurahan Bandungan. 


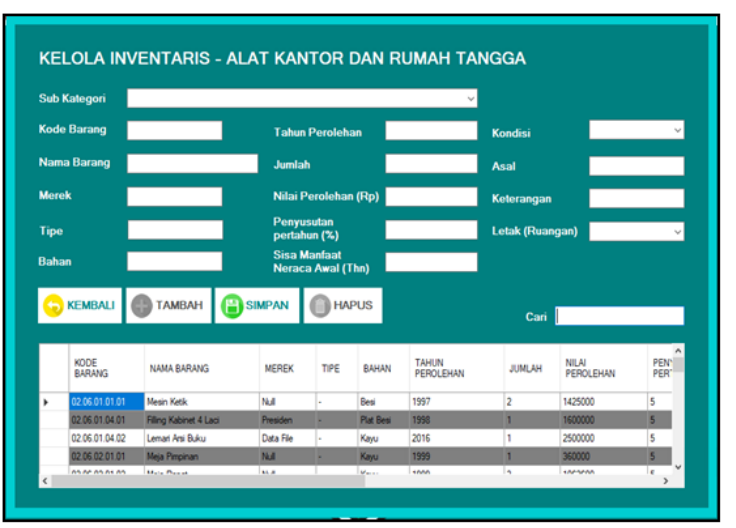

Sumber: Dikembangkan untuk penelitian ini

Gambar 10. Tampilan Form alat Kantor dan alat Rumah Tangga

Form kelola inventaris alat kantor dan alat rumah tangga adalah halam form untuk mengisi data-data inventaris alat kantor yang ada di Kantor Kelurahan Bandungan.

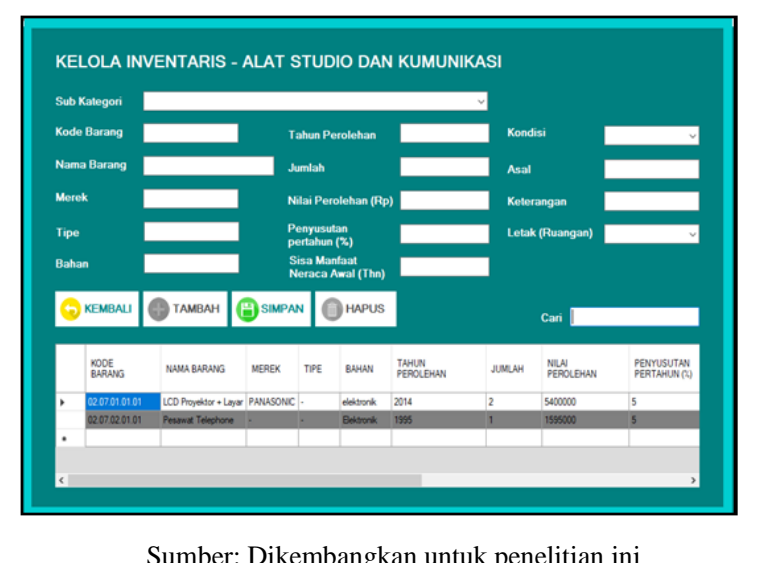

Gambar 11. Tampilan Form Alat Studio dan Komunikasi

Form kelola inventaris alat kantor dan alat rumah tangga adalah halam form untuk mengisi data-data inventaris alat kantor yang ada di Kantor Kelurahan Bandungan.

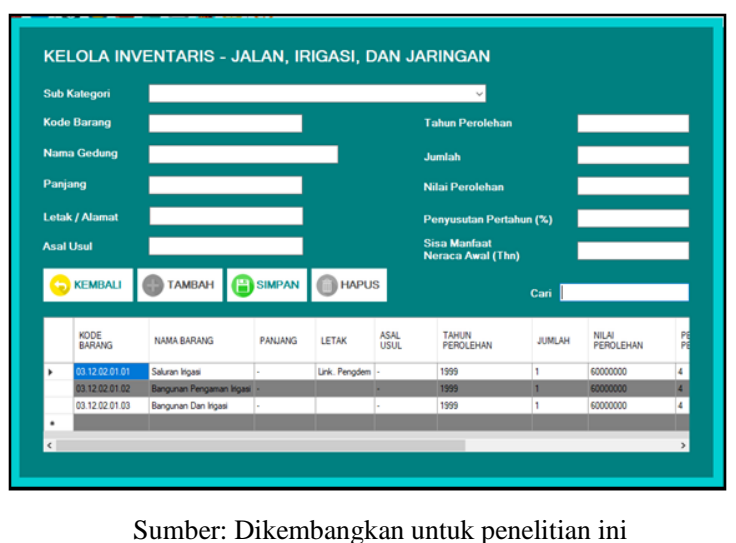

Gambar 12. Tampilan Form Jalan Irigasi dan Jaringan

Form kelola inventaris jalan irigasi dan jaringan adalah halam form untuk mengisi data-data inventaris jalan irigasi dan jaringan yang ada di Kantor Kelurahan Bandungan.

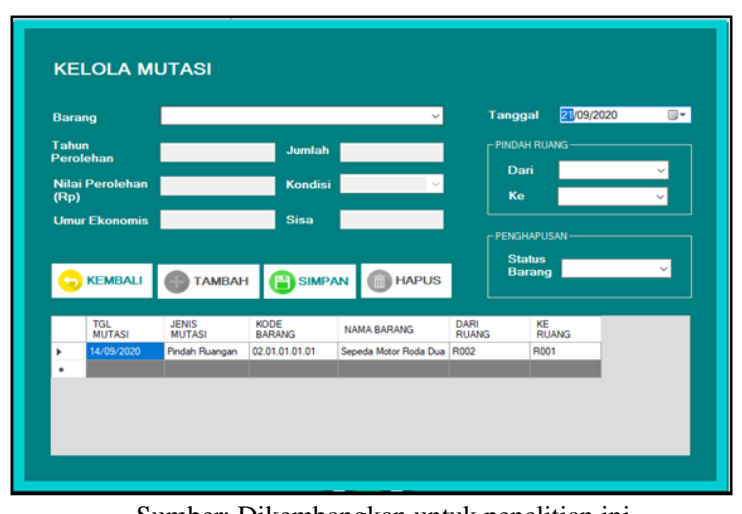

\section{Gambar 13. Tampilan Form Mutasi}

Form kelola mutasi adalah halam form untuk mengisi data-data hapus data barang atau data pindah ruangan yang ada di Kantor Kelurahan Bandungan.

\section{Conclusion}

Berdasarkan hasil penelitian yang dilakukan penulis, sistem ini memberikan kemudahan dalam proses pencatatan, proses perhitungan penyusutan serta pembuatan 
laporan secara otomatis. Sistem ini juga memiliki beberapa kelebihan antara lain: Pengolahan data di Kantor Kelurahan Bandungan lebih mudah karena seluruh data berada dalam satu program. Pembuatan laporan yang dibutuhkan menjadi lebih cepat dan akurat. Pendokumentasian data lebih baik dan terorganisir, karena data tersimpan dalam database.

Aplikasi yang dikembangkan dalam penelitian ini masih memiliki keterbatasan yaitu masih tidak bisa diakses secara online sehingga saran untuk penelitian selanjutnya yaitu pengembangan aplikasi yang dapat di akses secara online sehingga Pengurus pendataan Barang dapat dengan mudah mengerjakan atau membuat laporan di mana saja.

\section{DAFTAR PUSTAKA}

[1] Kusumajaya, A, Robby, Sembiring, Irwan, Iriani, Ade, "Analisis Kesiapan Tata Kelola Dan Investasi Sistem Informasi", Smart Comp, Volume 8 No. 2 Juni 2019.

[2] N. Herawati and L. Sunyata, "Strategi Penerapan Teknologi Informasi Di Pemerintah Kabupaten Sintang Provinsi Kalimantan Barat," J. Tesis PMIS-UNTAN-PSIAN, vol. 1, p. 22, 2013.

[3] Haryanto, "Dampak Perubahan Status Desa Menjadi Kelurahan Terhadap
Pelayanan Publik Di Kelurahan Paringin Kota Kabupaten Balangan," J. Ilmu Polit. Dan Pemerintah. Lokal, vol. 1, no. 2, p. 137, 2012.

[4] H. D. Nugroho, "Pengembangan Sistem Informasi Inventaris Barang Berbasis Website Di Smk Piri 2 Yogyakarta," Universitas Negeri Yogyakarta, Yogyakarta, 2018.

[5] PP RI NO. 24 TH 2005. (2007). SAP Standar Akutansi Pemerintahan. Yogyakarta : Pustaka Yustisia

[6] Minarni, \& Susanti. (2014). "Sistem Informasi Inventory Obat Pada Rumah Sakit Umum Daerah (RSUD) Padang". Momentum, 16(1), 103-111.

[7] Sari, A. O., \& Nuari, E. (2017). "Rancang Bangun Sistem Informasi Persediaan Barang Berbasis Web Dengan Metode Fast (Framework For The Applications)". Jurnal PILAR Nusa Mandiri, Vol. 13, N(2), 261266.

[8] Darwati, I. (2018). "Metode Waterfall Dalam Perancangan Program Pembelian Pada Toko Furniture", 6(1), 101-106.

[9] S. Gulo and R. J. Simamora, "Perancangan Sistem Informasi Administrai Rawat Inap Dan Rawat 
Jalan Pada Rumah Sakit Umum Siti

Hajar," vol. 2, no. 1, p. 13, 2018.

[10] Assey, T. B., Kalegele, K., \& Chachage, B. 2017. "Evaluating Information System Integration approaches for fixed asset management framework in Tanzania". Journal of Systems Integration, 4, 311.

[11] M. N. Witama, "Perancangan Aplikasi Pengelolaan Aset Barang Inventaris SDN Makasar 05 Pagi Jakarta Timur," STRING Satuan Tulisan Ris. Dan Inov. Teknol., vol. 3, no. 3, p. 211, Apr. 2019, doi: 10.30998/string.v3i3.3578.

[12] A. Y. Dwiantoro and R. B. Kusumandari, "Meningkatkan Hasil Belajar Berbasis E-learning Elgg pada Model Project Based Learning," Indones. J. Curric. Educ. Technol. Stud., vol. 4, p. 9, 2016.

[13] Sugiyono, Metode Penelitian Kuantitatif, Kualitatif, dan $R \& D$. Bandung: Alfabeta, 2017.

[14] Veza, O., \& Ropianto, M. (2017). "Perancangan Sistem Informasi Inventory Data Barang Pada Pt.Andalas Berlian Motors (Studi Kasus: PT Andalas Berlian Motors Bukit Tinggi)". Jurnal Teknik Ibnu Sina JT-IBSI, 2(2), 121-134.
[15] Dewi, Suryani, Janna M. Linda, Jumaryadi, Yuwan, "Analisis Dan Perancangan Sistem Informasi Manajemen Aset Tetap Pada PT. Metis Teknologi Corporindo", Jurnal Sistem Informasi, Teknologi Informatika dan Komputer, Volume 9, Nomor 1, September 2018. 